within 24 hours after the onset of continuous chest pain are given thrombolytic treatment. Patients with ST depression or deep $\mathrm{T}$ wave inversion are at first treated for unstable angina with heparin, aspirin, nitrates, and $\beta$ blockers. If chest pain persists after two hours and electrocardiographic changes show no tendency to resolve myocardial infarction is assumed and streptokinase infusion started. Early resolution of electrocardiographic changes, on the other hand, is taken to indicate reversible ischaemia requiring no additional treatment. No patient with a normal electrocardiogram receives thrombolytic treatment.

Consultant Cardiologist, Newham General Hospital,

ADAM D TIMMIS

London E13 8RU

1 Reimer KA, Jennings RB. The "wavefront phenomenon" of myocardial ischemic cell death. 2 Transmural progression of necrosis within the framework of ischemic bed size mvocardium at Transmural progression of necrosis within the fram
risk) and collateral flow. Lab Invest 1979;40:633-44.

2 Huey BL, Gheorghiade $M$, Crampton RS, et al. Acute non- $\mathrm{Q}$ wave myocardial infarction associated with early ST segment elevation: evidence for spontaneous coronary reperfusion and implications for thrombolytic trials. $7 \mathrm{Am}$ Coll Cardiol 1987;9:18-25.

3 Timmis AD, Griffin B, Crick JCP, Nelson DJ, Sowton E. The effects of early coronary patency on the evolution of myocardial infarction: a prospective arteriographic study. Br Hearl $f$ 1987;58:345-51.

4 Simoons ML, Serruys PW, Van den Brand M, et al. Early thrombolysis in acute myocardial infarction: limitation of infarct size and improved survival. $\mathcal{f}$. $m$ Coll Cardiol 1986;7:729-42.

5 White HD, Norris RM, Brown MA, et al. Effect of intravenous streptokinase on left ventricular function and early survival after acute myocardial infarction. $N$ Engl f Med 1987;317:850-5.

6 Gruppo Italiano per to Studio della Streptochinasi nell'Infarcto Miocardico. Effectiveness of intravenous thrombolytic treatment in acute myocardial infarction. Lancel 1986;i:397-402.

7 Second International Study of Infarct Survival. Randomised trial of intravenous streptokinase, oral aspirin, both, or neither among 17,187 cases of suspected myocardial infarction. Lancet
1988 ;ii:349-60.

8 Griffin B, Timmis AD, Crick JCP, Sowton E. The evolution of mrocardial ischaemia during percutaneous transluminal coronary angioplastv. Eur Heart 7 1987:8:347-53.

9 Norell MS, Lyons JP, Gershlick AH, et al. Assessment of teft ventricular performance during coronary angioplasty: a study of intravenous digital subtraction ventriculography. Br Heart $\mathcal{F}$ 1988;59:419-28.
10 Brush JF, Brand DA, Acamposa D, Chalmer B, Wackers FJ. Use of the electrocardiogram to predict in-hospital complications of acute myocardial infarction. $N$ Engl f Med 1985;312. $1137+1$

11 Lee TH, Rouan GW, Weisherg MC, et al. Sensitivity of routine clinical criteria for diagnosing myocardial infarction within 24 hours of hospitalization. Ann Intern. Med 1987;106:181-6.

12 Ruse RE, Poole K, Muller JE, et al. Electrocardiographic and clinical criteria for recognition of acute myocardial infarction based on the analysis of 3,697 patients. A $m$ f Cardiol 1983;52:936-42.

13 Yusuf S, Pearson M. Sterry H, et al. The entry ECG in the carly diagnosis and prognostic stratification of patients with suspected acute myocardial infarction. Eur Heart 7 1984;5:716-26. 4 Ashraf M, Sybers HD. Scanning electron microscopy of the heart after coronary occlusion. Lab Invest 1975;32:157-62

15 Jennings RB, Baum $\mathrm{JH}$, Herdson $\mathrm{PB}$. Fine structural changes in myocardial ischemic injury. Arch Pathol 1965;79:135-43.

16 Lee TH, Goldman L. Serum enzyme assays in the diagnosis of acute myocardial infarction recommendations based on a quantitative analysis. Ann Intern .Med 1986;105:221-33.

$17 \mathrm{Jaffe}$ AS, Serota H, Grace A, et al. Diagnostic changes in plasma creatine kinase isoforms early after the onset of acute myocardial infarction. Circulation 1986;74:105-9.

18 Morelli RI., Carlson CJ, Emilson B, et al. Serum creatine kinase MM isoenzyme sub-bands after acute mvocardial infarction in man. Circulation 1983:67:1283-9.

19 Granadier $\mathrm{F}$, Keider S. Kahana L, et al. The roles of serum myoglobin, total CPK, and CK-MB isoenzyme in the acute phase of myocardial infarction. Am Heart $f$ 1983;105:408-14.

20 Ohman EM, Casey C, Bengtson JR, Pryor D, Tormey W, Horgan JH. Early detection of acute myocardial infarction: additional diagnostic information from serum concentrations of myoglobin in patients without ST elevation. Br Heart f 1990;63:335-8.

21 Hangaard J, Rasmussen $O$, Norregaard-Hansen K, Jorgensen N, Simonsen EE, Norregaard Hansen B. Early diagnosis of acute myocardial infarction with a rapid latex agglutination test for semi-quantitative estimation of serum myoglobin. Acta Med Scand 1987;221:343-8.

2 Fitzgerald RJ, Tormey WP. A rapid slide agglutination test contrasted with a radioimmuoassay for myoglohin measurement for early diagnosis of myocardial necrosis. Ir f. Med Sci 1988;157:293-4.

23 Freeman AP, Fatches KR, Carter IW, Cloonan MJ, Wilcken DEL. Comparison of serum myoglobin and creatine kinase $\mathrm{MB}$ isoenzyme in early diagnosis of acute myocardial infarction BrHearl f 1981:45:389-92.

24 Collinson PO, Rosalki SB, Flather M, Wolman R, Evans T. Early diagnosis of myocardial infarction br timed sequential enzrme measurements. Ann Clin Biochem 1988:25:376-82.

25 Kallner A, Svlven C. Brodin L, Loogna E, Svenham K. Early diagnosis of acute myocardial infarction. A comparison between chemical predictors. Scand f Clin Lab Invest 1989:49:633-9.

26 Khaw BA, Beller GA, Haber F, Smith TW. Localization of cardiac myosin-specific antibody in myocardial infarction. $\mathcal{F}$ Clin Invest 1976;58:439-46.

27 Timmis AI), Lopez JA, Falon JT, Khaw BA, Haber E, Powell WJ. Detection of early necrosis in a canine model of low flow myocardial ischemia using "I-antimyson $(\mathrm{FAB})_{2}$. Fournal of Applied Cardiology 1987;2:185-211.

28 Jain D, Lahiri A, Raftery EB. Immunoscintigraphy for detecting acute myocardial infarction without electrocardiographic changes. Br Med 7 1990;300:151-3.

29 Wilcox RG, Von der Lippe G, Olsson CG, Jensen G, Skene AM, Hampton JR. Trial of tissuc plasminogen activator for mortality reduction in acute myocardial infarction: Anglo-Scandinavian study of early thrombolysis (ASSET). Lancet 1988;ii:525-30.

\title{
Flat feet in children
}

\section{Accurate diagnosis is the key}

Problems with children's feet illustrate several important general principles: that there is a wide range of normal in the developing child; that variations in shape are often transient and will correct with growth; that "flat feet" describes a deformity and is not necessarily a diagnosis; and that symptoms from the feet may indicate a more proximal disorder.

The shape of the foot depends on normal tarsal bones, normal articulation and ligamentous support between the tarsal bones, normal neuromuscular function, and, finally, a normal weight distribution from above - that is, a normally aligned leg. This is a lot of normals, each of which may be late to develop, and apparent foot abnormalities such as flat feet may occur at any time during growth.

At birth most infants' feet are in varying degrees of equinus, adduction, and inversion with an accentuated fat pad. On first standing, the child will usually adopt a wide stance and the flexible feet are forced into a pronated and everted position - they look like flat feet. ' With growth and development all those apparently abnormal factors that contributed to the formation of the flat foot are slowly and relentlessly corrected. By the age of 10 or so the tarsal bones have ossified and hardened, the ligamentous laxity of early childhood has resolved, the neuromuscular system has developed a fine motor control, and the normal leg alignment now provides for a normal load distribution from above, which leads to the feet adopting a normal shape.

Morley confirmed this natural resolution in his study of the natural course of footprints in children aged between 2 and
$10 .^{2} \mathrm{He}$ found that $97 \%$ of feet in children aged 2 were flat but only $4 \%$ persisted at age 10 . Painless and mobile flat feet in an otherwise normal young child do not require any treatment. Orthoses will not alter the natural correction - though sometimes heel cups and even special shoes are required to reassure parents. Some flat feet do persist, and usually a family history will be obtainable. Treatment will make no difference in these cases either.

Sometimes a child will have mobile flat feet that are painful, either locally within the foot or more proximally in the calf. Both types of pain are usually associated with activity, with the cramp in the calf often appearing at night some hours after the activity. Heel cups and moulded inserts will help to relieve symptoms. Even if the feet are persistently painful this is rarely severe enough to warrant surgery.

Flat feet may sometimes be secondary to a congenital or acquired condition that affects one or more of the main constituents of the normally functioning foot. When examining the foot, therefore, as well as looking for local abnormalities the clinician should be alert to changes in the shape or form of the foot that may point to disorders elsewhere. Many of the problems affecting the foot are difficult to diagnose at birth, but the abnormalities become apparent when the child starts to walk and deformity usually becomes more apparent with growth. By contrast, skeletal dysplasias or acquired problems such as cerebral palsy or meningomyelocoele can and should be diagnosed at birth. In such cases the foot should be looked at in the context of the overall management of the particular 
condition-for when treating some of these generalised conditions the foot is often forgotten and neglected and the opportunity to prevent deformity may be missed. Though serious neurological disorders are usually obvious, the development of flat feet may be the first and only manifestation of mild cerebral palsy. Tight heel cords may lead to eversion of the hind foot in an attempt to compensate for the contracted tendoachilles. This can happen at any age but often occurs during a growth spurt, and the child may be as old as 10 before symptoms occur.

Congenital bone deformities causing flat feet are rare; the feet are usually rigid, such that the deformity cannot be corrected easily by gentle manipulation and may be painful. Early diagnosis is mandatory to prevent secondary changes in other associated tarsal joints.

When there is a recognised cause for symptomatic flat feet the appropriate surgical procedures include lengthening the tendoachilles, reduction of the talonavicular and talocalcaneal subluxations in vertical talus, excision of a tarsal coalition, and excision of the accessory navicular. These procedures can relieve the symptoms successfully and lead to restoration of a normal functioning foot. By contrast, when the flat foot is painful and mobile without a recognised primary lesion surgery has had a chequered history, and few procedures have stood the test of time. Certain guidelines have been laid down and help to emphasise the need for the surgeon to make a careful assessment of both the feet and the patient. ${ }^{3}$ Firstly, do not operate for cosmetic reasons but only when there is considerable pain; secondly, the patient must be made aware of the consequent loss of movement and its implications; and, thirdly, most successful arthrodeses are of the subtalar joint either alone or in combination. Extra-articular procedures, such as osteotomy of the os calcis, have the advantage of correcting the flat foot deformity while maintaining joint function and not affecting growth in the child. These procedures enjoy a higher success rate in the longer term. ${ }^{+}$ Numerous other procedures have been described-but in the main they should be dismissed or even condemned. ${ }^{5}$

Consultant Orthopaedic Surgeon,

M A SMITH

St Thomas's Hospital,

London SE1 7EH

\footnotetext{
Rose GK. Pes planus. In: Jahss MH, ed. Disorders of the foot. Vol 1. Philadelphia: WB Saunders, 1982:486-520.

2 Morley AJM. Knock-knee in children. Br Med F 1957;ii:976-90

$3 \mathrm{Crego} \mathrm{CH}$, Ford LJ. An end result study of various operative procedures for correcting flat feet in children. 7 Bone foint Surg [Am] 1952;34:103-6.

Phillips GE. A.review of elongation of oscalcis for flat feet. F Bone foint Surg [Br] 1985;65:15-8.

5 Barry RJ, Cranton PE. Flat feet in children. Clin Orthop 1953;181:68-75.
}

\section{Forensic pathology: a blinkered report}

\section{Britain needs medicolegal institutes along European lines}

The state of forensic pathology in Britain has been a matter of concern for some time. ${ }^{12}$ The fact that many of the forensic pathologists of England and Wales are about to retire, some of them not to be replaced, prompted the Home Office to establish a working party to review the organisation and funding of the service. Five years later the working party has produced 25 pages of text and recommendations, ${ }^{3}$ which may well please the police, the government (which has accepted the recommendations), and some forensic pathologists but which fail to tackle the main problems.

Forensic pathology has been provided haphazardly ever since 1944, when the Home Office started to provide coroners and provincial police forces with a "list" of pathologists qualified to deal with suspicious deaths. Of the 45 pathologists now on the list, 22 work in the NHS, 12 in London medical schools, 10 in provincial medical schools, and one in independent practice. The annual cost of the service has been estimated at $£ 1 \mathrm{~m}$ (since acknowledged to be an underestimate), of which only a small part is paid by the Home Office and police. Most of the cost is borne by the universities, the NHS, and the pathologists themselves. The fees paid to pathologists for Home Office work are inadequate given its unpleasant nature and unsocial hours and compare unfavourably with those paid for routine coroner's necropsies. In London, moreover, forensic work for the police is done free, mainly by the staff of four medical schools, much of the rest of whose time is taken up with carrying out routine coroner's necropsies to provide money to finance their departmentswhich would otherwise close. Indeed, some pathologists, including three professors, have been told by their universities that they will not be replaced when they retire. In short, as the working party puts it, "The forensic pathology service of England and Wales consists of a group of independent medical practitioners who, pro bono publico, are willing to put their considerable expertise at the disposal of the police and the courts."

The time taken by the working party to produce its report raised hopes that it would propose some radical solutions. Instead, its proposals are based on the belief "that it would be wrong to change the basic structure of our present service whereby highly skilled individuals support the police . . . but retain their professional independence . . . whether as academics or as hospital consultants." What is proposed therefore is a package of measures designed to shore up the existing arrangements, even though, as the working party correctly points out, these "cannot be relied upon to continue to meet the needs of the police in the 1990s and beyond." A police advisory board for forensic pathology will advise the Home Office on all matters relating to forensic pathology and issue guidance to the police; the Home Office "list" is to be used for accreditation; the police in London will start to pay for their forensic pathology; fees are to be increased; the Home Office will fund senior lectureships in university departments, including the full costs of training two or three new forensic specialists each year; and some of the police's research and development funds are to be directed towards forensic pathology and related specialist disciplines.

The report makes no mention of the fact that Britain is almost unique in Europe in isolating forensic pathology from the rest of forensic science. It notes that toxicology, biochemistry, and analysis of weapons material have all become disciplines in their own right, so that "legal medicine now depends more than ever upon the close co-operation of experts in medicine and science." Yet it does not even mention the European medicolegal institutes, most of which provide a comprehensive forensic science service, including 